\title{
Problem-based learning as a valuable educational method for physically disabled teenagers? The discrepancy between theory and practice
}

Citation for published version (APA):

Könings, K., Wiers, R. W. H. J., van de Wiel, M. W. J., \& Schmidt, H. G. (2005). Problem-based learning as a valuable educational method for physically disabled teenagers? The discrepancy between theory and practice. Journal of Developmental and Physical Disabilities, 17(2), 107-117. https://doi.org/10.1007/s10882-005-3683-6

Document status and date:

Published: 01/01/2005

DOI:

10.1007/s10882-005-3683-6

Document Version:

Publisher's PDF, also known as Version of record

Please check the document version of this publication:

- A submitted manuscript is the version of the article upon submission and before peer-review. There can be important differences between the submitted version and the official published version of record.

People interested in the research are advised to contact the author for the final version of the publication, or visit the DOI to the publisher's website.

- The final author version and the galley proof are versions of the publication after peer review.

- The final published version features the final layout of the paper including the volume, issue and page numbers.

Link to publication

\footnotetext{
General rights rights.

- You may freely distribute the URL identifying the publication in the public portal. please follow below link for the End User Agreement:

www.umlib.nl/taverne-license

Take down policy

If you believe that this document breaches copyright please contact us at:

repository@maastrichtuniversity.nl

providing details and we will investigate your claim.
}

Copyright and moral rights for the publications made accessible in the public portal are retained by the authors and/or other copyright owners and it is a condition of accessing publications that users recognise and abide by the legal requirements associated with these

- Users may download and print one copy of any publication from the public portal for the purpose of private study or research.

- You may not further distribute the material or use it for any profit-making activity or commercial gain

If the publication is distributed under the terms of Article $25 \mathrm{fa}$ of the Dutch Copyright Act, indicated by the "Taverne" license above, 


\title{
Problem-Based Learning as a Valuable Educational Method for Physically Disabled Teenagers? The Discrepancy Between Theory and Practice
}

\author{
Karen D. Könings, ${ }^{1,4}$ Reinout W. Wiers, ${ }^{2}$ \\ Margaretha W. J. van de Wiel, ${ }^{2}$ and Henk G. Schmidt ${ }^{3}$
}

Previous research indicated that physically disabled children have a low selfefficacy and perceive less control over their own performance than other children. Problem-based learning (PBL) is an educational approach that emphasizes interpersonal skills, self-directed learning and problem-solving skills. Acquiring these skills has been demonstrated to increase self-efficacy. This study examined whether the use of PBL would increase self-efficacy and school-related attitudes in physically disabled teenagers. In a quasiexperimental design, 29 physically disabled teenagers received a 9-week geography course in PBL format or their usual geography education. Contrary to our hypothesis, no positive effects of PBL were found and the PBL group even showed a significant decrease in learning-related self-esteem, as compared with the controls. A possible explanation is that the PBL course was too short and not integrated in the whole curriculum. The results emphasize the importance of experimentally testing the effects of new educational methods for use in other populations then the population for which positive results have been reported (university students). This seems particularly true in special populations such as physically disabled children. Additionally,

\footnotetext{
${ }^{1}$ Open University of the Netherlands.

${ }^{2}$ Maastricht University, The Netherlands.

${ }^{3}$ Erasmus University Rotterdam, The Netherlands.

${ }^{4}$ To whom correspondence should be addressed at Open University of the Netherlands, Educational Technology Expertise Center, P.O. Box 2960, 6401 DL Heerlen, The Netherlands; e-mail: karen.konings@ou.nl.
} 
carefully monitoring the implementation process seems especially important here.

KEY WORDS: physically disabled children; problem-based learning; secondary education; social-emotional development.

Previous research has demonstrated that physical illness or disabilities are associated with psychosocial problems (e.g. Cadman et al., 1987). These psychosocial problems are often concentrated around lack of self-esteem, lack of motivation for challenging and independent tasks, and learned helplessness (Kunnen, 1992, 1993). Another relevant concept here is "selfefficacy" (Bandura, 1977), which is defined as the conviction that someone can successfully execute the behavior required to produce the desired outcomes. If someone seriously doubts her or his capability to perform the required activities, little energy and time will be spend in trying to reach the goal. Negative expectations of oneself and the future are positively correlated with depression and negatively correlated with self-esteem (Kazdin et al., 1986). Cadman et al. (1987) have demonstrated that physically disabled children have a more than doubled risk for psychosocial problems, and are at substantially higher risk for psychiatric problems like depression than their non-handicapped peers.

Kunnen $(1992,1993)$ has suggested that interventions for physically disabled children should be directed at improving the perceived control over own performances (as the opposite of learned helplessness) and motivation to work independently. School is a social institution that can support the mastering of these skills. It influences the child's affective development (Oatley and Nundy, 1998), for instance, by the kind of instruction that is used in an educational setting. According to Boekaerts (1996), indirect forms of instruction foster the ability to motivate oneself, to take initiative, to be persistent, to take responsibility for learning, and to be able to work independently or in groups. In indirect instruction, the learning process is active, self-organized and self-controlled. Through a process of learning, using problem-solving skills, and attaining perceived control, people develop positive beliefs about themselves and their future (Palmer and Wehmeyer, 1998). Promoting this process could be favorable for physically handicapped children.

Problem-based learning (PBL) is an instructional method, with a big emphasis on self-regulated learning (Norman and Schmidt, 1992; Zimmerman and Lebeau, 2000). Small groups of students discuss problem descriptions, which are constructed by their teacher. The task of the student group is to discuss these problems, based on their prior knowledge. During 
the initial discussion dilemmas will arise and questions will come up that will direct subsequent individual self-directed learning. After a period of self-study, students come back in the group and discuss the problem once again. The newly acquired knowledge is actively applied and students check whether the problems can be solved. Afterwards a new cycle begins and students start working on a new problem.

Research has shown that PBL increases confidence and motivation of students (Agbor et al., 2000), promotes greater acquisition of psychosocial knowledge, enhances interpersonal skills, and encourages students to become engaged and self-directed learners (Block, 1996). Furthermore, PBL promotes critical thinking and a problem-solving way of working (Birgegard and Lindquist, 1998; but see Norman and Schmidt, 1992). Most of these positive results of PBL, however, are based on studies with university students, so it is not clear yet if these effects would also appear for students of secondary education. Nevertheless, from the available literature about positive effects of PBL on university students, it can be expected that PBL could also have favorable effects on physically disabled students. The hypothesis of the current study was that PBL enhances the self-efficacy and learning-related attitudes, including motivation for schoolwork, self-esteem and well being, in physically disabled secondary school students.

\section{METHOD}

\section{Participants}

The participants were students of two different special schools for physically disabled students. The students were 8th and 9th graders of the lower level of general secondary education. Their primary problems are physical ones; they did not have serious cognitive dysfunctions. Their overall intelligence was comparable with healthy peers in normal secondary schools and they get the same certificates. The physical problems of the students ranged from cerebral palsy, muscle dystrophy, spinal cord lesion and psychomotor retardation to rheumatism and kidney diseases. The experimental PBL group consisted of 15 students of one school (divided in three groups, mean age 17.1), and the control group consisted of 14 participants of another school (divided in two groups, mean age 15.6). Because of the limited number of students in this type of special education, it was not possible to create a PBL condition and a control condition in the same school. In order to match the PBL group and the control group, school grades were used as criterion: all participants were in the 8 th or 9th grade. 
There was an unintended significant age difference between both groups $(t(27)=3.5, p=.002)$.

\section{Design}

This experiment used a quasi-experimental split-plot design, consisting of two conditions and two measurement moments per participant (repeated measures). Between the pretest and the posttest, the experimental group received its geography education in a PBL format for a period of 9 weeks; the control group received an unchanged curriculum.

\section{Measures}

During the pretest and the posttest, each student filled out two psychological questionnaires:

1. The Dutch translation of the General Self-Efficacy Scale (Sherer et al., 1982), as described in Bosscher et al. (1997). This questionnaire consists of 12 self-report items and measures the level of selfefficacy on a 5-point Likert scale.

2. The Dutch Schoolvragenlijst (Vorst, 1990), abbreviated SVL, measures students' attitudes toward school and toward their own learning-processes on three subscales: motivation for schoolwork, self-esteem or self-concept, and the well being and social-emotional attitude toward school life. The first 80 items (part A) of the test were used in this study. The self-report items have to be scored on a 3-point scale: don't agree, no opinion, agree.

At the end of the experimental course, students of the PBL group completed a knowledge test consisting of eight open-ended questions that related closely to the contents of the problems discussed in the meetings. The written answers were assessed by the teacher on a 10-point scale. The students in the control group did not complete this knowledge test because they did not study the same learning content in that period. In the PBL condition, in addition, both the teacher and the first author observed and separately judged the overall functioning of each student in the PBL system on a 10-point scale. These judgments were based on a general impression of functioning during the initial discussions and the reporting discussions. The results of the knowledge test and the observation together will be called external assessments, as opposed to self-report measures. Finally, the students of the PBL group were asked about their experiences with PBL, using a short questionnaire. 


\section{Materials}

Two experimental coursebooks were developed by the first author to guide geography education in a problem-based fashion to the PBL group. Each coursebook contained nine problems. One coursebook was about the European Union and was used by the 8th graders. The coursebook for the 9th graders dealt with environmental planning and livability in the Netherlands. Besides the coursebook, the students were provided with complementary texts of different geography books about the themes of the problems.

In developing the coursebooks, several principles of PBL have been used (see e.g., Norman and Schmidt, 1992; Schmidt and Moust, 1999, 2000). The first important principle of the PBL system is the activation of prior knowledge. Activating existing knowledge has a big influence on the processing of new information. The educational materials of this study consisted of problem descriptions that are easily imaginable for the students and easily provoke discussion. It was expected that students had enough prior knowledge to discuss the problems. The initial discussions and the activated prior knowledge are the starting point for self-study. Second, the PBL system attaches great importance to elaboration of the learning content. Actively working with the subject matter and looking for connections promotes remembering and retrieving later on. The initial discussions and the self-study stimulate engagement in the subject matter. The problems used were intended to stimulate the application of the learning content to specific problems. During the reporting discussions, the tutor encouraged the students to elaborate and connect parts of information. Third, PBL should enhance intrinsic motivation to learn, because students get confronted with realistic problems and because the initial discussions stimulate looking for solutions of the problems described. Therefore, problems consisted of descriptions of real-life problems, which are geared to the students' perception of their environment, and the educational materials were made as attractive as possible, using pictures to make the problems concrete and easy to visualize.

\section{Procedure}

After the pretest, the 15 students of the PBL condition (divided into three groups) received a training, to get acquainted with the way of working in PBL. Subsequently, each group had one meeting of 90 min every week, in which the students reported the information they had studied about the problem, and discussed a new problem, which they had to study for next time (in line with the standard PBL routine, Schmidt and Moust, 2000). The 
mean group size during the meetings in the PBL condition was 4.4 students $(S D=1.28)$, due to incidental absence of single students. The control group received the usual geography course. At the end of the experimental period, there was a posttest of self-efficacy and learning-related attitudes in both conditions. The PBL group additionally completed a knowledge test.

\section{Statistical Analyses}

The hypothesis was that there would be an interaction between time and condition, with self-efficacy and learning-related attitudes increasing more strongly in the PBL group than in the control group. To compare the pretest and the posttest, a repeated measures analysis was used. Because of the small sample size, the power of this experiment was not very high. Therefore, it was decided to cautiously interpret statistical trends $(.05<p<.10)$, in addition to statistically significant effects $(p<.05)$. Part of the data of this study was based on students' self-reports, and the other part on the assessment of the functioning of the students during the group meetings by the teacher and the first author. The average of the assessment scores of both judges was used, because they were highly correlated $(r=.94, p<.01)$. In order to get an impression of the association between the students' self-reports and the external assessments, correlations were computed between those measures.

\section{RESULTS}

Although there was an age difference between the PBL group and the control group, age did not significantly contribute to the prediction of the Self-efficacy Scale $(F(1,26)=1.8, p=.19)$, nor to the prediction of the $\operatorname{SVL}(F(1,25)=1.23, p=.28)$. For that reason, age is not included as covariate in the analyses that follow.

The analysis of the Self-Efficacy Scale showed no significant effect of time, $F(1,27)=1.01, p=.32$. The effect of condition was marginally significant, $F(1,27)=2.88, p=.10$. The control group scored higher on the

Table I. Mean Scores and Standard Deviations of the Self-Efficacy Scale

\begin{tabular}{lcclcc}
\hline & \multicolumn{2}{c}{ Pretest } & & \multicolumn{2}{c}{ Posttest } \\
\cline { 2 - 3 } \cline { 5 - 6 } Self-Efficacy Scale & $M$ & $S D$ & & $M$ & $S D$ \\
\hline Experimental group & 43.9 & 2.1 & & 42.2 & 2.4 \\
Control group & 45.6 & 2.2 & & 44.8 & 2.5 \\
\hline
\end{tabular}




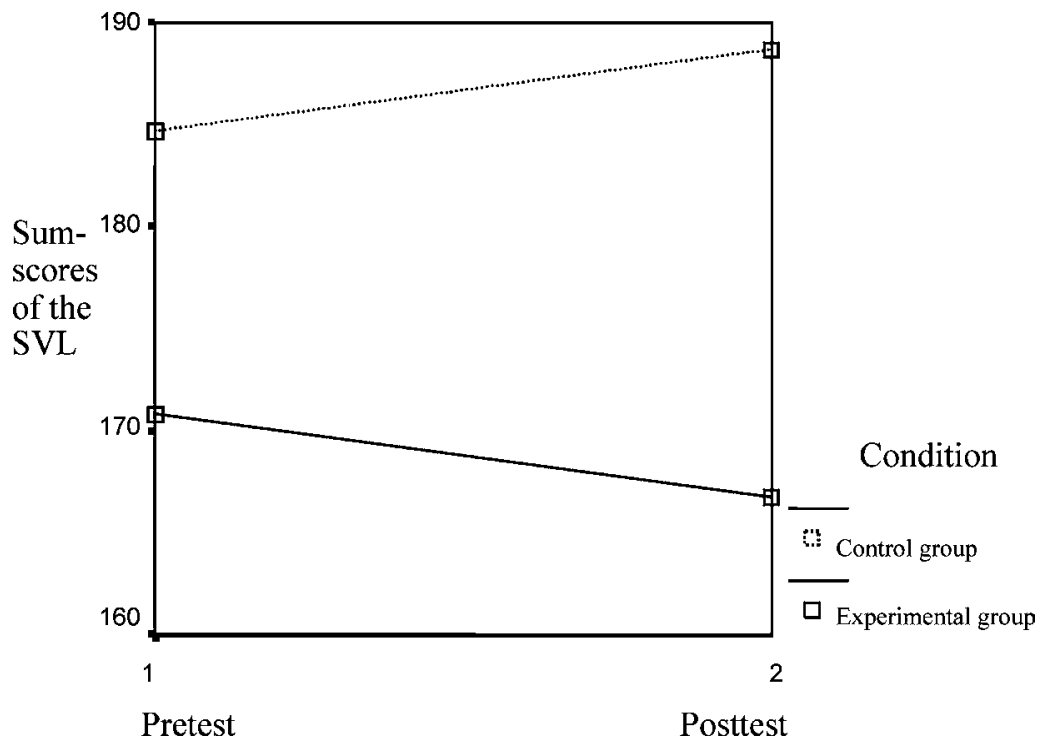

Fig. 1. Sumscores of the SVL as a function of time.

Self-Efficacy Scale than the PBL group, independent of the time of measurement. There was no interaction of time and condition; $F(1,27)=2.02$, $p=.66$. So, the expected positive effect of PBL on self-efficacy was not confirmed. See Table I for an overview of the data.

The sumscore of the SVL gives a general measurement of students' attitudes toward school and their own learning processes. A higher score means a more positive attitude. There was no significant effect of time, $F(1,26)=.0001, p=.98$. The effect of condition was significant, $F(1,26)=$

Table II. Mean Scores and Standard Deviations of the SVL

\begin{tabular}{lrrrrr}
\hline & \multicolumn{2}{c}{ Pretest } & & \multicolumn{2}{c}{ Posttest } \\
\cline { 2 - 3 } \cline { 5 - 6 } \multicolumn{1}{c}{ SVL } & $M$ & $S D$ & & $M$ & $S D$ \\
\hline PBL group & & & & \\
Sumscore & 173.5 & 6.5 & & 169.2 & 5.6 \\
Subscale motivation & 59.0 & 3.1 & & 56.9 & 2.8 \\
Subscale well being & 64.7 & 2.2 & & 62.9 & 2.0 \\
Subscale self-esteem & 49.8 & 2.5 & & 49.3 & 2.6 \\
& & & & \\
Control group & & & & \\
Sumscore & 181.6 & 6.7 & & 185.9 & 6.1 \\
Subscale motivation & 59.4 & 3.4 & & 59.5 & 3.1 \\
Subscale well being & 62.1 & 2.4 & & 61.3 & 2.2 \\
Subscale self-esteem & 60.0 & 2.7 & 65.1 & 2.6 \\
\hline
\end{tabular}


Table III. Pearson Correlations of Self-Reported Self-Efficacy and the External Assessments of the Functioning in PBL

\begin{tabular}{lcc}
\hline & $\begin{array}{r}\text { Knowledge test } \\
\text { (at the posttest) }\end{array}$ & $\begin{array}{c}\text { Functioning in PBL } \\
\text { (at the posttest) }\end{array}$ \\
\hline Self-efficacy at the pretest & $.70^{*}$ & $.53^{*}$ \\
Self-efficacy at the posttest & .34 & .30 \\
\hline${ }^{*} p<.05$. & &
\end{tabular}

$5.48, p=.027$. The data showed a marginally significant interaction of time and condition, $F(1,26)=3.93, p=.058$. Note that the direction of the effect was opposite to the expected direction, as depicted in Fig. 1. The school- and learning-related attitudes, as measured in terms of motivation for schoolwork, self-esteem and well being, became more negative in the PBL group and more positive in the control group.

In order to explore what changed in the opposite direction, the subscales of the SVL were further analyzed separately (see Table II). The subscale self-esteem was the one subscale that showed significant results. There was a significant time-effect, $F(1,26)=4.94, p=.035$, a significant condition-effect, $F(1,26)=16.98, p<.001$, and a significant interaction effect of time and condition, $F(1,26)=5.86, p=.023$. Again contrary to the hypothesis, self-esteem increased in the control group and remained equal in the PBL group. This is remarkable, because self-esteem was higher in the control group already at the pretest, and nevertheless it was this group that showed an increase in self-esteem.

Table III shows the correlations between self-reported self-efficacy, and the external assessments. These correlations show an interesting pattern. There are significant correlations between the self-perceived selfefficacy on the pretest and the externally perceived efficacy of performance on the posttest. This means that there is a strong relation between students' ideas about their own capacities at the beginning and the actual performances at the time of the posttest. However, self-perceived selfefficacy at posttest does not correlate significantly with externally perceived efficacy of performance. Students judged themselves more negatively than the teacher and the first author did at the posttest. This could indicate that students underestimated their own performance after the PBL course.

\section{DISCUSSION}

The current study did not confirm the hypothesis (based on ample research with university students) that PBL would enhance self-efficacy and 
learning-related attitudes of physically disabled students. For some variables (i.e. school-related self-esteem), even an opposite effect was found. What could explain these unexpected results?

A possible explanation for this negative result could be that the period of the intervention was too short to find the positive effects of PBL. Most of the positive effects, which are described in the literature, were found after a longer period of PBL. Real effects of implementing PBL can be best perceived only after a period of adjustment, in which problems that arise in early stages of implementing PBL have been overcome (Khoo, 2003). Furthermore, in the beginning of working with a new curriculum, many students realize their lack of control over their own learning process (Boekaerts, 1996). This may have caused feelings of helplessness. The evaluation at the end of the PBL period of the current study confirmed that students expressed dissatisfaction especially with the lack of explanation of the teacher, the self-study, the need to communicate and their independence. Unfortunately, students developed more negative attitudes toward school and their own learning processes during the PBL intervention. Probably students felt confronted with a learning situation that they were not master of and that did not provide enough time and support to acquire the necessary skills. The correlation pattern between self-efficacy and external assessments of the functioning in PBL provides support for this interpretation.

Some limitations of this study might explain why the expected positive effects of PBL failed to occur. First, only a small part of the curriculum was given in a PBL format. The students worked just $1.5-2 \mathrm{~h}$ a week in the PBL discussion groups; the remaining time they followed traditional lessons. Usually in PBL, the whole curriculum is designed in that manner (see e.g., Schmidt, 1993; Schmidt and Moust, 2000; Wiers et al., 2002). Second, there appeared to be a school effect. The scores of control group and the PBL group differed at pretest. This problem was related to the quasiexperimental design used here, which was chosen because schools for physically disabled students are too small to test two conditions in one setting. Third, the discussion groups were quite small. Although not much is known about the optimal group size (Albanese and Mitchell, 1993), experiences during this study pointed out that the group functioning was hampered in groups smaller than four students.

\section{GENERAL CONCLUSION}

This study shows that although the literature provides indications that PBL can have positive effects on self-efficacy, motivation and well being, 
there is no guarantee that the desired outcomes will be obtained in physically disabled students. It has been shown that a lot of factors influence the effects of an implementation and that the process should be monitored accurately (see, e.g., Albanese and Mitchell, 1993; Khoo, 2003; Schmidt and Moust, 2000). The result of this study also showed that it is difficult to draw strong conclusions from the results of small-scale implementation. In our opinion, however, it is worth trying to stimulate the social-emotional development of physically disabled students in everyday school life, by means of indirect instruction forms. If PBL was implemented for a longer period of time, it is possible that the desired effects will appear because students would have the opportunity to overcome feelings of uncertainty and to acquire the PBL-related skills that are important to become psychologically empowered individuals. A practical implication of this study is that in the case of implementing didactics that require more self-regulation of students, one should be attentive to an initial decline in self-esteem of the students. In the beginning, students need some extra support and must get the opportunity to acquire the essential self-regulation skills. Only after a longer period of experiences with a new instructional method, research can show whether the desired effects really appear. This is particularly true when implementing new didactics in schools for special populations such as physically disabled children.

\section{REFERENCES}

Agbor, B. W., Gordon, P. R., and Harper, E. T. (2000). The value of problem-based learning as an orientation tool. Acad. Med. 75(6): 567.

Albanese, M. A., and Mitchell, M. A. (1993). Problem-based learning: A review of literature on its outcomes and implementation issues. Acad. Med. 68(1): 52-81.

Bandura, A. (1977). Self-efficacy: Toward a unifying theory of behavioral change. Psychol. Rev. 84(2): 191-215.

Birgegard, G., and Lindquist, U. (1998). Change in student attitudes to medical school after the introduction of problem-based learning in spite of low ratings. Med. Educ. 32: 46-49.

Block, S. D. (1996). Using problem-based learning to enhance the psychosocial competence of medical students. Acad. Psychiatry 20(2): 65-75.

Boekaerts, M. (1996). Personality and the psychology of learning. Eur. J. Personality 10: $377-$ 404.

Bosscher, R. J., Smit, J. H., and Kempen, G. I. J. M. (1997). Algemene competentieverwachtingen bij ouderen: Een onderzoek naar de psychometrische kenmerken van de Algemene Competentieschaal (ALCOS) (General competence expectations of elderly people: A investigation into the psychometric characteristics of the General Competence Scale). Nederlands tijdschrift voor de psychologie 52: 239-248.

Cadman, D., Boyle, M., Szatmari, P., and Offord, D. R. (1987). Chronic illness, disability, and mental and social well-being: Findings of the Ontario Child Health Study. Pediatrics 79(5): 805-813.

Kazdin, A. E., Rodgers, A., and Colbus, D. (1986). The hopelssness scale for children: Psychometric characteristics and concurrent validity. J. Consult. Clin. Psychol. 54(2): 241-245. 
Khoo, H. E. (2003). Implementation of problem-based learning in Asian medical schools and students' perceptions of their experience. Med. Educ. 37(5): 401-409.

Kunnen, E. S. (1992). Mastering (with) a handicap: The development of task-attitudes in physically handicapped children. Unpublished doctoral dissertation, University of Groningen, The Netherlands.

Kunnen, E. S. (1993). Attributions and perceived control over school failure in handicapped and non-handicapped children. Int. J. Behav. Dev. 16(1): 113-123.

Norman, G. R., and Schmidt, H. G. (1992). The psychological basis of problem-based learning: A review of the evidence. Acad. Med. 67(9): 557-565.

Oatley, K., and Nundy, S. (1998). Rethinking the role of emotions in education. In Olson, D. R., and Torrance, N. (eds.), The Handbook of Education and Human Development, Oxford: Blackwell Publishers Ltd, pp. 257-274.

Palmer, S. B., and Wehmeyer, M. L. (1998). Students' expectations of the future: Hopelessness as a barrier tot self-determination. Mental Retard. 36(2): 128-136.

Sherer, M., Maddux, J. E., Mercandante, B., Prentice-Dunn, S., Jacobs, B., and Rogers, R. W. (1982). The self-efficacy scale: Construction and validation. Psychol. Rep. 51: 663-671.

Schmidt, H. G. (1993). Foundations of problem-based learning: Some explanatory notes. Med. Educ. 27(5): 422-432.

Schmidt, H. G., and Moust, J. H. C. (1999). A taxonomy of problems used in problem-based curricula. In van Merriënboer, J., and van Moerkerke, G. (eds.), Instructional Design for Problem-Based Learning: Proceedings of the Third Workshop of the EARLI SIG Instructional Design, Maastricht: Datawyse, pp. 3-12.

Schmidt, H. G., and Moust, J. H. C. (2000). Factors affecting small-group tutorial learning: A review of research. In Eversen, D. H., and Hmelo, C. E. (eds.), Problem-Based Learning: A Research Perspective on Learning Interactions, Mahwah, NJ: Lawrence Erlbaum (pp. 19-52).

Vorst, H. C. M. (1990). Handleiding and verantwoording bij de SchoolVragenLijst. [Manual] Nijmegen: Berkhout.

Wiers, R. W., van de Wiel, M. W. J., Sá, H. L. C, Mamede, S., Tomaz, J. B., and Schmidt, H. G. (2002). Design of a problem-based curriculum. A general approach and a case study in the domain of public health. Med. Teacher 24: 45-51.

Zimmerman, B. J., and Lebeau, R. B. (2000). A commentary on self-directed learning. In Eversen, D. H., and Hmelo, C. E. (eds.), Problem-Based Learning: A Research Perspective on Learning Interactions, Mahwah, NJ: Lawrence Erlbaum, pp. 299-314. 